\title{
Review
}

\section{The regulation of glucose transport in insulin-sensitive cells}

\author{
H.G.Joost ${ }^{1}$ and T.M.Weber ${ }^{2}$ \\ ${ }^{1}$ Institute of Pharmacology and Toxicology, University of Göttingen, FRG and ${ }^{2}$ National Institutes of Health, \\ LBM/NIDDK, Bethesda, Maryland, USA
}

Stereospecific transport of D-glucose into muscle and adipose tissue is the rate limiting step of glucose utilization in mammals. This transport process is tightly regulated by insulin and counterregulatory factors such as catecholamines and glucagon. For the study of glucose transport regulation, the ideal model is the isolated adipocyte because of the large effect of insulin, the homogeneity of the cell preparation, and the relative ease of the procedures to obtain well-defined membrane fractions which retain a large effect of insulin [1-3]. Muscle tissue, in contrast, does not offer these advantages. Thus, the majority of studies on insulin action has been performed in adipocytes. This review will, therefore, focus mainly on findings obtained with fat cells. However, the crucial findings, such as the translocation of transporters in response to insulin and the counterregulatory effect of catecholamines, have been confirmed in studies with muscle tissue which will be discussed briefly.

\section{The mechanism of insulin action}

\section{The translocation mechanism}

The stimulatory effect of insulin on glucose transport in the adipocyte persists after homogenization of cells and can be demonstrated in an isolated plasma membrane preparation [4]. This so-called fossil effect has facilitated the study of insulin action and has ultimately provided the crucial finding that adipocytes contain a large intracellular pool of glucose transporters from which transporters are translocated to the plasma membrane when cells are exposed to insulin [5-9]. Thus, it was concluded that an increase in the concentration of transporters in the plasma membrane accounts for the stimulatory effect of insulin on the transport activity. Similar findings have been obtained in muscle [10], indicating that insulin-induced translocation of glucose transporters is common to insulin-sensitive tissue. Several other proteins are translocated in response to insulin, e.g. the insulin-like growth factor II/mannose-6-phosphate receptor [11] and the transferrin receptor [12]. Comprehensive reviews on the translocation process have been published previously [13-15].

\section{The structure of the glucose transporter}

The first primary sequence of a glucose transporter protein was established by analysis of a clonal cDNA from a human hepatoma cell line, the HepG2 cell [16]. Later, a cDNA with $97.6 \%$ homology was isolated from rat brain [17]. Expression of the protein in Escherichia coli induced a stereospecific glucose transport activity [18]. It was first believed that this transporter sequence, the HepG2 cell/erythrocyte/brain glucose transporter (GT1), is highly conserved, since mRNA hybridizing with the cDNA under stringent conditions was found in most tissues $[17,19]$. However, screening a variety of tissues under less stringent conditions has led to the identification of other cDNAs encoding transporter-like proteins from liver [20] (liver glucose transporter, GT2), and from muscle [20-22], adipose tissue [23] and differentiated 3T3-L1 cells [24] (muscle/adipose tissue glucose transporter, GT3). Thus, a family of glucose transport proteins exists, and most tissues appear to express more than one type of transporter.

The possible existence of a transporter unique to insulin-sensitive tissues was first demonstrated with a monoclonal antibody generated from a transporter preparation from adipocytes [25]. The subsequent cloning experiments verified the unique sequence [20-24], and further raised the question whether insulin sensitivity of a cell is conferred by the amino acid sequence of its glucose transporter, its post-translational processing, and/or by an unknown ability of the cellular machinery. Previous data suggest that other constitutive transport proteins present in an insulin-responsive cell may respond to the hormone. In addition to GT3, the tissue specific glucose transporter, adipocytes express the transporter protein GT1. This protein was detected 


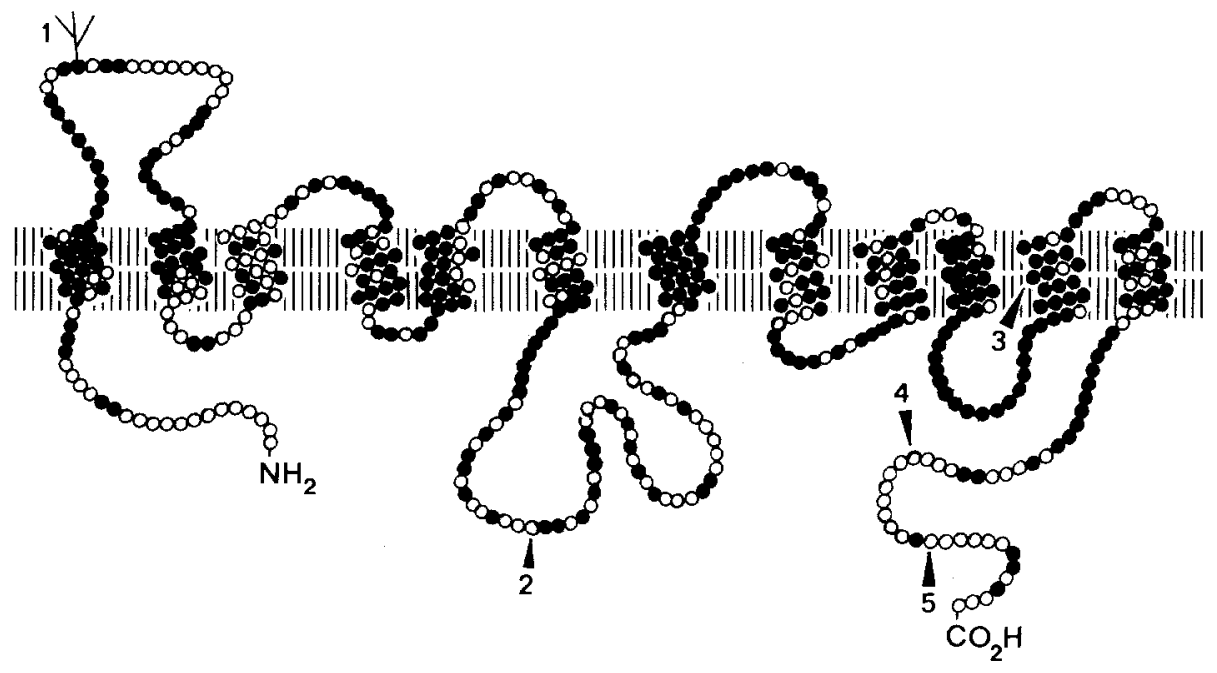

Fig. 1. Presumed membrane topology of the rat muscle/adipose tissue glucose transporter (GT3). Sequence and topology of membrane spanning regions have been adopted from Birnbaum (22). Filled symbols denote amino acids identical in the brain/erythrocyte/HepG2-cell glucose transporter (GT1). 1, presumed glycosylation site Asn 57 (45 in GT1); 2, 4, and 5 , possible phosphorylation sites Ser 246 (226 in GT1), Ser 488 and Ser $497 ; 3$, putative cytochalasin B binding site Trp 428 (412). The cytoplasmic side of the membrane faces downwards with antisera against the human erythrocyte glucose transporter or against peptides derived from the sequence of the GT1 [26-30] which has only $63.5 \%$ homology with the GT3. Nevertheless, it has been demonstrated by a variety of techniques that the GT1 undergoes the characteristic insulin-dependent translocation process in the adipocyte $[9,26-28,30-32]$. Thus, the data indicate that at least two transporters (GT1 and GT3) are translocated in response to insulin. Therefore, if the primary structure confers insulin sensitivity of muscle and adipose tissue, the important structural regions must be homologous to GT1 and GT3. In the future, transfection studies in concert with specific peptide-derived antibodies will help to elucidate the relative contribution of the different transporters to the overall effect of insulin. In addition, site-directed mutagenesis and construction of chimeras will define the particular domains interacting with the translocating elements in the machinery of an insulin-responsive cell.

\section{Changes of the transporter intrinsic activity by insulin}

In spite of the substantial evidence that insulin triggers the insertion of intracellularly stored glucose transporters into the plasma membrane, two lines of evidence suggest that an additional activation of the glucose transporter might contribute to the effect of the hormone. Firstly, the quantitative comparison of transport activity and number of transporters in basal and insulin-stimulated cells and membrane fractions revealed that translocation cannot account for all of the effect of insulin in the adipocyte [30]. Secondly, in addition to the augmentation of transporters in the plasma membrane, the hormone produces several qualitative alterations of the glucose transporter [30, 33-36].

Only a portion of the effect of insulin appears to be retained in membranes from cells exhibiting a large response to the hormone. In cells, insulin can stimulate the transport rate up to 30 -fold, whereas, the largest re- sponse in plasma membranes reported so far is a 15fold stimulation of transport activity [30]. Thus, insulin appears to activate either the translocated glucose transporters or carriers constitutively residing in the plasma membrane.

Recently, an elegant method has been described which labels glucose transporters in plasma membranes of 3T3-L1 adipocytes by oxidation and subsequent tritiation of galactose residues [31]. With this method, it was possible to more directly compare transport activity with transporter concentration, and again a significant discrepancy was found. Unfortunately, this study and others which have quantitated the transporter by techniques dependent on antisera have used sera specific for the GT1 and thus, have looked at only a portion of the total glucose transporters. The conclusions of these studies must be reconsidered after the relative numbers and the activity of each of the transporter species is known.

A decrease in the transport $\mathrm{K}_{\mathrm{m}}$ has recently been reported in highly insulin-responsive adipocytes [33-34]. In other studies, however, the $\mathrm{K}_{\mathrm{m}}$ of glucose transport in basal and insulin-stimulated cells was indistinguishable $[2,30,37,38]$. The divergent reports can be reconciled with the assumption that the incubation conditions, mainly the pattern of cell agitation and the cell concentration, determine whether an effect of insulin on transport $\mathrm{K}_{\mathrm{m}}$ is observed or not. If cells were moderately agitated (shaking at $40 \mathrm{cycles} / \mathrm{min}$ ) and a cell concentration of approximately $2 \times 10^{6} / \mathrm{ml}$ was not exceeded, no change in the transport $\mathrm{K}_{\mathrm{m}}$ was detected either in cells or in plasma membranes prepared from these cells [30]. It appears quite possible that a higher cell concentration and incubation without any agitation gives rise to the accumulation of metabolites which increase the transport $\mathrm{K}_{\mathrm{m}}$. The effect of insulin would then be a reversal of this effect. Nevertheless, the effect of the hormone on the transport $\mathrm{K}_{\mathrm{m}}$ confirms that insulin may change transporter function as well as their number. 


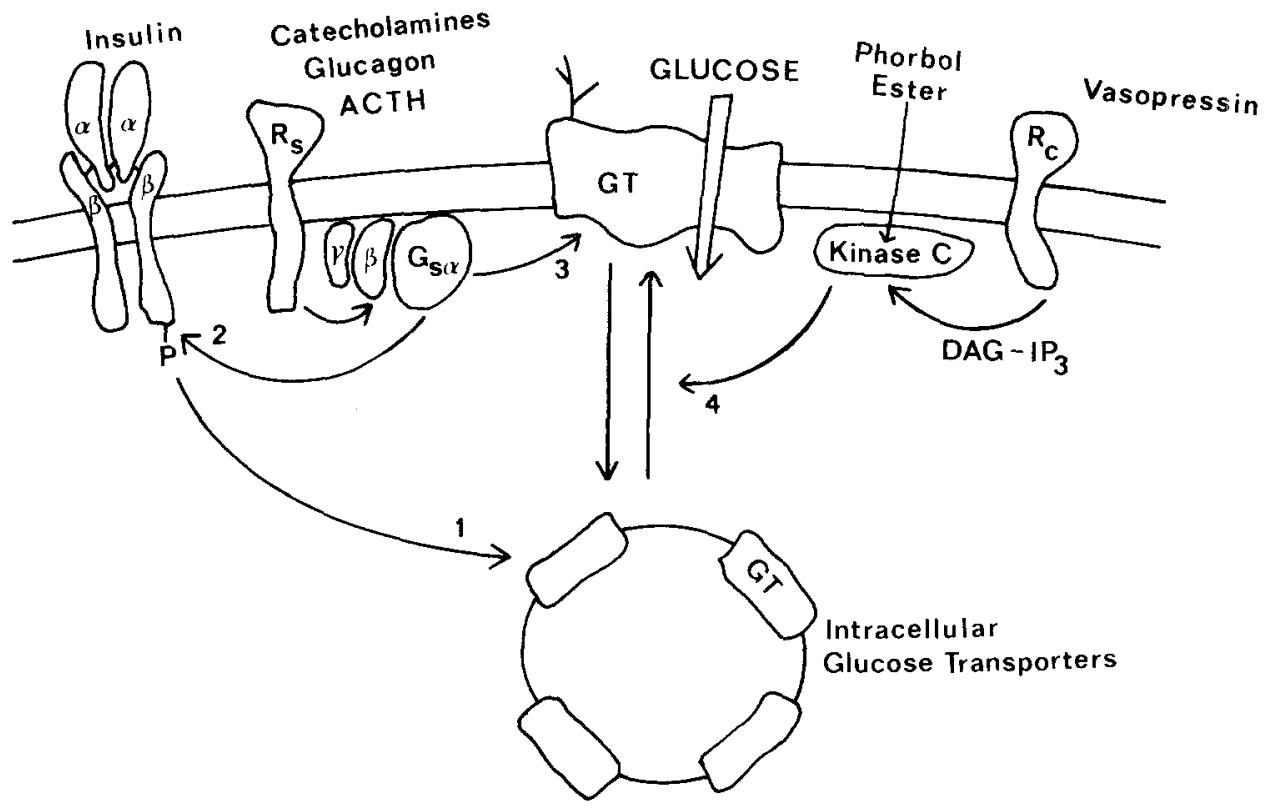

Fig. 2. Schematic summary of the mechanisms involved in glucose transport regulation in the adipocyte. 1, insulin-induced translocation of glucose transporters to the plasma membrane, presumably mediated by a phosphorylation cascade; 2 , inhibition of insulin receptor autophosphorylation by lipolytic agents e.g. catecholamines, reducing insulin-induced translocation of glucose transporters; 3 , decrease in glucose transporter activity by lipolytic agents, mediated by an interaction of the guanine nucleotide-binding protein $\mathrm{G}_{\mathrm{S}}$ with the trans-

The temperature dependence of glucose transport activity in membranes from basal cells differs from that in membranes prepared from insulin-treated cells [30]. Consequently, the relative response to insulin as assayed in the membranes increases with the temperature ( 15 -fold at $37^{\circ} \mathrm{C}$ as compared to 10 -fold at $20^{\circ} \mathrm{C}$ ). Recently it was reported in a preliminary study that the activity of reconstituted glucose transporters was reduced by guanine nucleotides provided that cells were treated with insulin prior to isolation of membrane fractions $[35,36]$. It was concluded that insulin had rendered the transporter sensitive to guanine nucleotides. Taken together, these findings suggest that the effect of insulin on the glucose transporter is not limited to a simple augmentation of its number in the plasma membrane, but comprises an array of functional changes.

\section{Signal transduction via the receptor tyrosine kinase and a phosphorylation cascade}

The action of insulin is initiated by binding to a specific membrane receptor [for a recent review see ref.39]. This receptor has an intrinsic protein kinase activity localized in the $\beta$-subunit which stimulates its autophosphorylation on tyrosine residues [40]. Activation of the receptor kinase is the most rapid event following binding of insulin to the receptor [41] and may be the unique signalling mechanism for all actions of insulin. It is be- porter or by its phosphorylation; 4, translocation of glucose transporters by agents activating protein kinase C. For clarity's sake, the model largely simplifies the depicted mechanisms. The effects of adenosine and other antilipolytic agents, and the presumed change in transporter intrinsic activity by insulin and agents stimulating kinase $C$ are not included in the illustration. $R_{s}$, receptor species stimulating adenylate cyclase; $R_{c}$, receptor species stimulating kinase $C$; GT, glucose transporter; DAG, diacylglycerol; $\mathrm{IP}_{3}$, inositol-1,4,5-trisphosphate

yond the scope of this review to comprehensively present the evidence in favour of such a signalling mechanism, but the crucial pieces of data linking the receptor kinase to glucose transport will be discussed briefly with some findings contradicting such a mechanism. Recently, site-directed insulin receptor mutants lacking the tyrosine phosphorylation sites [42] or the ATP-binding site [43] have been inserted into insulin-sensitive cells. In these cell lines, the effect of insulin on 2-deoxyglucose transport was impaired in parallel to the inhibition of tyrosine kinase. Further, injection of a monoclonal antibody, which specifically inhibited the tyrosine kinase activity of the receptor, into Chinese hamster ovary cells inhibited the effect of insulin on 2-deoxyglucose transport, phosphorylation of ribosomal protein S6, and glycogen synthesis [44]. On the basis of these data, it can be concluded that the tyrosine kinase activation of the insulin receptor is required for the examined metabolic effects of insulin.

In contrast to these findings, other studies have dissociated tyrosine kinase activation and glucose transport stimulation. A full insulinomimetic effect on glucose transport was observed in human adipocytes treated with a monoclonal antibody to the insulin receptor which antagonized the receptor kinase [45]. Furthermore, in isolated adipocytes only a minute portion of the maximal tyrosine kinase activity needs to be activated in order to produce full stimulation of glucose transport activity $[46,47]$. Moreover, the finding that a 
covalently dimerized insulin derivative $[48,49]$ is a pure agonist in stimulating glucose transport but a partial agonist of the tyrosine kinase may indicate that different receptors are responsible for the two processes. Finally, insulin-like growth factor II stimulates a large increase in glucose transport activity in 3T3-L1 adipocytes probably via its own receptor [50] which does not possess a tyrosine kinase domain [51].

After receptor occupation and autophosphorylation, several uncharacterized proteins in plasma membranes, intracellular microsomes, and cytosol are phosphorylated on tyrosine residues [52-55]. These findings have supported the hypothesis that a phosphorylation cascade mediates and amplifies the intracellular action of insulin $[56,57]$. However, the mechanism of signal transduction from the receptor-mediated tyrosine phosphorylation to the rapid changes in glucose metabolism is still not completely understood. Serine kinases appear to be involved, since insulin activates acetyl-CoA carboxylase by phosphorylation on serine residues [58]. Several insulin-dependent serine kinases have been found, and their activation through tyrosine phosphorylation has been suggested recently $[59,60]$. Furthermore, some insulin-induced metabolic changes are mediated by dephosphorylation of enzymes, e.g. triglyceride lipase [61] and glycogen synthase [62], requiring the activation of an insulin-dependent phosphatase. At present, it is unclear whether insulin changes the phosphorylation state of the transporter. Previous studies have failed to detect any phosphate incorporation into the transporter immunoprecipitated with antiserum against GT1 [63, 64]. In contrast, insulin was found to stimulate phosphate incorporation into the transporter detected by a monoclonal antibody against GT3 [65]. However, using the same antibody another group failed to observe this effect of insulin [66]. Interestingly, one of the insulin-dependent serine kinases phosphorylates the microtubule-associated protein MAP-2 [60]. It is tempting to speculate on a role of the microtubular system in mediating insulin dependent translocation of proteins.

Phosphorylation of the $\alpha$-subunits of guanine nucleotide binding proteins (G-proteins) in response to insulin has been related to the phosphorylation cascade on the basis of the finding that the purified insulin receptor kinase phosphorylates the $\alpha$-subunits of $G_{i}, G_{0}$, and of transducin [67-69]. However, no phosphorylation of G-protein $\alpha$-subunits was detected in immunoprecipitates from intact cells equilibrated with $\left[{ }^{32} \mathrm{P}\right]$ phosphate and treated with insulin [70, 71]. These data argue against a mediating role of phosphorylated G-protein $\alpha$-subunits in insulin action.

In summary, there is little doubt that phosphorylation reactions, initiated by an insulin-dependent serine kinase, play a crucial role in the mechanism of signal transduction. As far as the role of the tyrosine kinase activity of the insulin receptor is concerned, some divergent findings still must be reconciled, and the presumed tyrosine phosphorylation of serine kinases has to be es- tablished unequivocally. The link between phosphorylation reactions and the translocation of glucose transporters is unclear; speculation might link the MAP-2 kinase [60] to these events.

\section{Counterregulatory inhibition of glucose transport by catecholamines}

Catecholamines reduce insulin-stimulated glucose transport activity in adipocytes provided that the inhibitory regulation of adenylate cyclase via $G_{i}$ is not operative [72-75]. Conversely, antilipolytic agents e.g. adenosine reverse this effect, and produce a moderate augmentation of the insulin-stimulated transport activity $[73,76,77]$. Similar effects have been observed in skeletal muscle [78]. The inhibitory effect of catecholamines in adipocytes reflects both a shift of the concentration-response curve to higher insulin concentrations and a marked reduction of the maximal effect of insulin $[15,79]$. As is discussed below, the first component may be attributed to inhibition of the insulin receptor kinase, whereas the latter effect appears to reflect a change in intrinsic activity of glucose transporters.

\section{Inhibition of the insulin receptor tyrosine kinase activity}

Several previous studies have suggested that catecholamines affect insulin receptor binding and/or function. When adipocytes incubated at a high cell concentration were exposed to isoproterenol, the affinity of insulin receptors was reduced $[80,81]$. Similar data were obtained by stimulation of adenylate cyclase with the adenosine antagonist, theophylline [82]. Since the effect of the lipolytic agents was less pronounced when cells were incubated at lower cell concentrations, it appeared to be produced by a reduction of cellular ATP-levels [83, 84] due to intracellular accumulation of fatty acids or a drop in $\mathrm{pH}$ of the incubation medium [85] caused by the release of fatty acids. Under carefully controlled incubation conditions which prevent accumulation of fatty acids and keep the $\mathrm{pH}$ of the incubation medium constant, no change of receptor affinity but a moderate $(20 \%)$ reduction of plasma membrane receptors was observed [79]. These receptors appeared to be internalized, since insulin binding in low-density microsomes was increased in response to the catecholamine. More importantly, catecholamines appear to also affect the tyrosine kinase activity of the receptor. Again, the effect is much smaller under carefully controlled incubation conditions [79] than if cells are incubated at a high concentration [86], but could account for the shift of the concentration-response curve to higher insulin concentrations. Total as well as tyrosine phosphorylation of the receptor $\beta$-subunit is decreased [79]. Altogether, the data indicate that catecholamines impair insulin receptor kinase activity and thereby reduce insulin sensitivity of adipocytes. 


\section{Alteration of transporter activity by catecholamines}

In addition to an inhibition of the insulin receptor kinase, a second mechanism which is unrelated to the translocation process is responsible for the effect of catecholamines on glucose transport [87]. Unlike that of insulin, the effect of catecholamines is rapidly reversed by cooling the cells to $22^{\circ} \mathrm{C}$ and subsequent homogenization. The reversal can be blocked by addition of $\mathrm{KCN}$ to the cells prior to cooling and homogenization. With this procedure, plasma membranes can be prepared which exhibit a transport $V_{\max }$ reduced by $40-60 \%$ without any change in the number of cytochalasin $\mathrm{B}$ binding sites due to the isoproterenol treatment. In addition, the affinity of the cytochalasin B binding site was significantly reduced, whereas the immunoreactivity of the plasma membrane glucose transporter was unchanged by the catecholamine [64]. These data led to the conclusion that catecholamines decrease the transporter intrinsic activity [87]. The opposite effect, an increase in the intrinsic activity of the transporter, appears to occur in response to adenylate cyclase inhibitors, since adenosine stimulates the transport activity in addition to counteracting the inhibitory effect of isoproterenol via $\mathrm{G}_{\mathrm{i}}$ activation [77, 87].

A comparison of changes in cAMP levels and activity of the cAMP-dependent kinase [77] revealed that these alterations can be dissociated from catecholamine-induced changes in transport activity. Thus, it was suggested that intrinsic activity changes of glucose transporters were not mediated by cAMP and the cAMP-dependent protein kinase but rather by a direct interaction of the transporter with guanine nucleotidebinding proteins. Consistent with this conclusion, no phosphorylation of the glucose transporter GT1 was observed in response to catecholamines [64]. In contrast, in a preliminary study, phosphorylation of GT3 was reported in response to isoproterenol [66]. On the other hand, other preliminary data indicate that guanine nucleotides can indeed inhibit glucose transport activity reconstituted from adipocyte membrane fractions $[35,36]$ in the absence of ATP; conditions unlikely to increase cAMP levels, A-kinase activity and the phosphorylation state of the transporter. Thus, further experiments are required to determine whether the intrinsic activity changes produced by catecholamines and adenosine reflect phosphorylation of the transporter or its interaction with G-proteins.

\section{Effects of agents activating protein kinase C}

Phorbol esters produce a stimulation of glucose transport in adipocytes [88] as well as in a muscle-like cell line [89]. This effect is probably mediated through protein kinase $\mathrm{C}$, since other agents stimulating kinase $\mathrm{C}$ e.g. vasopressin produce similar effects [90]. In addition, phorbol esters stimulate phosphate incorporation into glucose transporters in adipocytes [64]. Like that of insulin, the stimulatory effect of phorbol esters on glucose transport activity appears to be due to translocation of transporters. However, a striking discrepancy between the number of transporters and transport activity was observed in adipocytes after treatment with the phorbol esters $[90,91]$. The stimulatory effect of the agents on transport activity approached only about $10 \%$ of that produced by insulin, but reflected a translocation of glucose transporters which was $50 \%$ of that in response to insulin [90]. Thus, it may been concluded that phorbol esters induce the translocation of inactive transporters.

\section{Agents affecting transport activity by binding to the transporter}

\section{Forskolin}

The diterpene forskolin is one of the most powerful stimulators of adenylate cyclase [92] and has thus been widely used to characterize cAMP-dependent mechanisms [93]. However, several effects of forskolin have been described which appeared to occur independent of a stimulation of adenylate cyclase. Forskolin is a powerful inhibitor of glucose transport in erythrocytes, adipocytes and platelets, and it has been shown that the inhibitory effect of the diterpene reflects a direct interaction with the transporter [94-96]. A comparison of the relative potencies of forskolin and four forskolin derivatives in inhibiting glucose transport and stimulating adenylate cyclase was performed in rat adipocyte plasma membranes. This study revealed that forskolin initiates adenylate cyclase stimulation and glucose transport inhibition at different sites [97]. Recently, the photoreactive, iodinated forskolin derivative, 3 - iodo - 4 azidophenethylamido - 7 - 0 - succinyldeacetylforskolin, has been synthesized [98]. In erythrocytes, the photolabel covalently binds to an intrinsic membrane protein identified as the glucose transporter by its molecular weight and by tryptic peptide analysis [98]. Furthermore, the compound specifically labelled a protein in adipocytes, tentatively identified as the glucose transporter (GT1 and/or GT3), which changes its cellular distribution in response to insulin $[99,100]$.

\section{Methylxanthines and inhibitors of nucleoside transport}

Methylxanthines, e.g. theophylline, are potent inhibitors of glucose transport activity in adipocytes [83]. Since this effect could be dissociated from their effects on cAMP-levels, a direct interaction of the agents with the glucose transport has been proposed [101]. Similarly, inhibitors of nucleoside transport (dipyridamole, nitrobenzylthioguanosine, nitrobenzylthioinosine and papaverine) are also potent inhibitors of glucose transport in rat adipocytes [102]. Moreover, these agents inhibit the specific binding of cytochalasin B to the glu- 
cose transporter [102]. Thus, glucose and nucleoside transporters appear to possess a similar site mediating an inhibitory regulation of their function. It is tempting to speculate that these sites, presumably located at the cytoplasmic surface of the membrane, are receptors for an endogenous ligand which adjusts the transport capacity of the cell to rapid changes of its metabolism.

\section{Concluding remarks}

Convincing evidence indicates that glucose transport activity in insulin-sensitive cells is regulated by translocation of intracellular transporters to the plasma membrane. In addition, the intrinsic activity of the transporter is regulated by insulin and catecholamines. Current research is focussed on the molecular basis of these changes, and circumstantial evidence suggests involvement of a guanine nucleotide-dependent mechanism, or a phosphorylation of the transporter. The signalling chain linking the insulin receptor to glucose transport activation is as yet not fully understood. It is reasonable to assume that a phosphorylation/dephosphorylation cascade mediates the metabolic effects of insulin. A currently debated question is whether the glucose transporter is phosphorylated in response to insulin. Alternatively, the phosphorylation of a protein associated with the intracellular vesicles containing the glucose transporters, or of a microtubule-associated protein, might be involved in the translocation process.

Acknowledgements. We wish to thank Drs. S.W.Cushman and I. A. Simpson for their support and many helpful discussions.

\section{References}

1. Rodbell M (1964) Metabolism of isolated fat cells: effects of hormones on glucose metabolism and lipolysis. J Biol Chem 239: $375-380$

2. Gliemann J, Rees WD (1983) The insulin-sensitive hexose transport system in adipocytes. Curr Topics Membr Transp 18: 339-379

3. Weber TM, Joost HG, Simpson IA, Cushman SW (1988) Methods for assessment of glucose transport activity and the number of glucose transporters in isolated rat adipose cells and membrane fractions. In: Kahn CR, Harrison L (eds) Receptor biochemistry and methodology. Insulin receptors part B: biological responses, and comparison to the IGF-I receptor. Liss, New York, pp 171-187

4. Martin DB, Carter JR (1970) Insulin-stimulated glucose uptake by subcellular particles from adipose cells. Science 167:873-874

5. Wardzala LJ, Cushman SW, Salans LB (1978) Mechanism of insulin action on glucose transport in the isolated rat adipose cell. Enhancement of the number of functional transport systems. J Biol Chem 253: 8002-8005

6. Suzuki K, Kono T (1980) Evidence that insulin causes a translocation of glucose transport activity to the plasma membrane from an intracellular storage site. Proc Natl Acad Sci USA 77: 2542-2545

7. Cushman SW, Wardzala LJ (1980) Potential mechanism of insulin action on glucose transport in the isolated rat adipose cell. Apparent translocation of intracellular transport systems to the plasma membrane. J Biol Chem 255: 4758-4762

8. Kono T, Suzuki T, Dansey LE, Robinson FW, Blevins TL (1981) Energy-dependent and protein synthesis-independent recycling of the insulin-sensitive glucose transport mechanism in fat cells. J Biol Chem 256: 6400-6407

9. Blok J, Gibbs ME, Lienhard GE, Slot JW, Geuze HJ (1988) Insulin-induced translocation of glucose transporters from postGolgi compartments to the plasma membrane of 3T3-L1 adipocytes. J Cell Biol 106: 69-76

10. Wardzala LJ, Jeanrenaud B (1981) Potential mechanism of insulin action on glucose transport in the isolated rat diaphragm. Apparent translocation of intracellular transport units to the plasma membrane. J Biol Chem 256: 7090-7093

11. Wardzala LJ, Simpson IA, Rechler MM, Cushman SW (1984) Potential mechanism of the stimulatory action of insulin on insulin-like growth factor II binding to the isolated rat adipose cell. Apparent redistribution of receptors cycling between a large intracellular pool and the plasma membrane. J Biol Chem 259: 8378-8383

12. Davis RJ, Corvera S, Czech MP (1986) Insulin stimulates cellular iron uptake and causes the redistribution of intracellular transferrin receptors to the plasma membrane. J Biol Chem 261: 8708-8711

13. Kono $T$ (1984) Translocation hypothesis of insulin action on glucose transport. Fed Proc 43: 2256-2257

14. Simpson IA, Cushman SW (1985) Hexose transport regulation by insulin in the isolated rat adipose cell. In: Czech MP (ed) Molecular basis of insulin action. Plenum, New York, pp 399-422

15. Simpson IA, Cushman SW (1986) Hormonal regulation of mammalian glucose transport. Ann Rev Biochem 55: 1059-1089

16. Mueckler M, Caruso C, Baldwin SA, Panico M, Blench I, Morris HR, Allard WJ, Lienhard GE, Lodish HF (1985) Sequence and structure of human glucose transporter. Science 229: 941-945

17. Birnbaum M, Haspel HC, Rosen OM (1986) Cloning and characterization of a cDNA encoding the rat brain glucose-transporter protein. Proc Natl Acad Sci USA 83: 5784-5788

18. Sarkar NK, Thorens B, Lodish HF, Kaback HR (1988) Expression of the human erythrocyte glucose transporter in Escherichia coli. Proc Natl Acad Sci USA 85: 5463-5467

19. Flier JS, Mueckler M, McCall AL, Lodish HF (1987) Distribution of glucose transporter messenger RNA transcripts in tissues of rat and man. J Clin Invest 79: 657-661

20. Fukumoto H, Kayano T, Buse JB, Edwards Y, Pilch PF, Bell GIY, Seino S (1989) Cloning and characterization of the major insulin-responsive glucose transporter expressed in human skeletal muscle and other insulin-responsive tissues. J Biol Chem 264: 7776-7779

21. Charron MJ, Brosius FC, Alper SL, Lodish HF (1989) A glucose transport protein expressed predominately in insulin responsive tissues. Proc Natl Acad Sci USA 86: 2535-2539

22. Birnbaum MJ (1989) Identification of a novel gene encoding an insulin-responsive glucose transporter protein. Cell 57: 305-315

23. James DE, Strube M, Mueckler M (1989) Molecular cloning and characterization of an insulin-regulatable glucose transporter. Nature 338: 83-87

24. Kaestner KH, Christy RJ, McLenithan JC, Braiterman LT, Cornelius P, Pekala PH, Lane MD (1989) Sequence, tissue distribution, and differential expression of mRNA for a putative insulinresponsive glucose transporter in mouse 3T3-L1 adipocytes. Proc Natl Acad Sci USA 86: 3150-3154

25. James DE, Brown R, Navarro J, Pilch PF (1988) Insulin regulatable tissues express a unique insulin-sensitive glucose transport protein. Nature 333: 183-185

26. Wheeler TJ, Simpson IA, Sogin DC, Hinkle PC, Cushman SW (1982) Detection of rat adipose cell glucose transporter with antibody against the human red cell glucose transporter. Biochem Biophys Res Commun 105: 89-95

27. Lienhard GE, Kim HH, Ransome KJ, Gorga JC (1982) Immunological identification of an insulin-responsive glucose transporter. Biochem Biophys Res Commun 105: 1150-1156

28. Haspel HC, Rosenfeld MG, Rosen OM (1988) Characterization of antisera to a synthetic carboxyl-terminal peptide of the glucose transporter protein. J Biol Chem 263: 398-403 
29. Oka Y, Asano T, Shibasaki Y, Kasuga M, Kanazawa Y, Takaku F (1988) Studies with antipeptide antibody suggest the presence of at leâst two types of glucose transporter in rat brain and adipocyte. J Biol Chem 263: 13432-13439

30. Joost HG, Weber TM, Cushman SW (1988) Qualitative and quantitative comparison of glucose transport activity and glucose transporter concentration in plasma membranes from basal and insulin-stimulated rat adipose cells. Biochem J 249:155-161

31. Calderhead DM, Lienhard GE (1988) Labeling of glucose transporters at the cell surface in 3T3-L1 adipocytes. Evidence for both translocation and a second mechanism in the stimulation of transport. J Biol Chem 263: 12171-12174

32. Gould GW, Derechin V, James DE, Tordjman K, Ahern S, Gibbs M, Lienhard GE, Mueckler M (1989) Insulin-stimulated translocation of the HepG2/erythrocyte-type glucose transporter expressed in 3T3-L1 adipocytes. J Biol Chem 264: 2180-2184

33. Whitesell RR, Abumrad NA (1986) Modulation of basal glucose transporter $\mathrm{K}_{\mathrm{m}}$ in the adipocyte by insulin and other factors. J Biol Chem 261: 15090-15096

34. Toyoda N, Flanagan JE, Kono T (1987) Reassessment of insulin effects on the $V_{\max }$ and $\mathrm{K}_{\mathrm{m}}$ values of hexose transport in isolated rat epididymal adipocyte. J Biol Chem 262: 2737-2745

35. Schürmann A (1989) Glucose transport activity reconstituted from adipocyte membrane fractions: differential effects of guanine nucleotides in membranes from basal and insulintreated cells. Naunyn-Schmiedeberg's Arch Pharmacol 339 [Suppl.]: R34 (Abstract)

36. Schürmann A, Rosenthal W, Hinsch KD, Joost HG (1989) Differential sensitivity to guanine nucleotides of basal and insulinstimulated glucose transporter activity reconstituted from adipocyte membrane fractions. FEBS Lett., 255: 259-264

37. Taylor LP, Holman GD (1981) Symmetrical kinetic parameters for 3-0-methyl-D-glucose transport in adipocytes in the presence and in the absence of insulin. Biochim Biophys Acta 642: 325-355

38. Martz A, Mookerjee BD, Jung CY (1986) Insulin and phorbol esters affect the maximum velocity rather than the half-saturation constant of 3-0-methylglucose transport in rat adipocytes. J Biol Chem 261: 13606-13609

39. Carpientier J-L (1989) The cell biology of the insulin receptor. Diabetologia 32: 627-635

40. Kasuga M, Karlsson FA, Kahn CR (1982) Insulin stimulates the phosphorylation of the 95,000 -dalton subunit of its own receptor. Science 215: 185-187

41. Pang DT, Sharma BR, Shafer JA, White MF, Kahn CR (1985) Predominance of tyrosine phosphorylation of insulin receptors during initial response of intact cells to insulin. J Biol Chem 260: 7131-7136

42. Ellis L, Clauser E, Morgan DO, Edery M, Roth RA, Rutter WJ (1986) Replacement of insulin receptor tyrosine residues 1162 and 1163 compromises insulin-stimulated kinase activity and uptake of 2-deoxyglucose. Cell 45: 721-732

43. Ebina Y, Araki E, Taira M, Mori M, Craik CS, Siddle K, Pierce SB, Roth RA, Rutter WJ (1987) Replacement of lysine residue 1030 in the putative ATP-binding region of the insulin receptor abolishes insulin- and antibody-stimulated glucose uptake and receptor kinase activity. Proc Natl Acad Sci USA 84: 704-708

44. Morgan DO, Roth RA (1987) Acute insulin action requires insulin receptor kinase activity: introduction of an inhibitory monoclonal antibody into mammalian cells blocks the rapid effects of insulin. Proc Natl Acad Sci USA 84: 41-45

45. Forsayeth JR, Caro JF, Sinha MK, Maddux BA, Goldfine ID (1987) Monoclonal antibodies to the human insulin receptor that activate glucose transport but not insulin receptor activity. Proc Natl Acad Sci USA 84: 3448-3451

46. Weber TM, DiPaolo S, Joost HG, Cushman SW, Simpson IA (1988) Subcellular distribution of insulin receptor tyrosine kinase activity in rat adipocytes. In: Goren HJ, Hollenberg MD, Roncari DAK (eds) Insulin action and diabetes. Raven Press, New York, pp 151-156

47. Klein HH, Freidenberg GR, Kladde M, Olefsky JM (1986)
Insulin activation of insulin receptor tyrosine kinase in intact rat adipocytes. An in vitro system to measure histone kinase activity of insulin receptors activated in vivo. J Biol Chem 261: 4691-4697

48. Joost HG, Göke R, Steinfelder HJ, Brandenburg D (1988) Dissociation of glucose transport and tyrosine kinase activation in isolated adipocytes with a covalently dimerized insulin derivative. Diabetes 37 [Suppl.1]: 87A (Abstract)

49. Joost HG, Göke R, Schmitz-Salue C, Steinfelder HJ, Brandenburg D (1989) Quantitative dissociation of glucose transport stimulation and insulin receptor tyrosine kinase activation in isolated adipocytes with a covalent insulin dimer (B29,B29'suberoyl-insulin). Biochem Pharmacol 38: 2269-2277

50. Kohansky RA, Frost SC, Lane MD (1986) Insulin-dependent phosphorylation of the insulin receptor-protein kinase and activation of glucose transport in 3T3-L1 adipocytes. J Biol Chem 261: 12272-12281

51. Morgan DO, Edman JC, Standring DN, Fried VA, Smith MC, Roth RA, Rutter WJ (1987) Insulin-like growth factor II receptor as a multifunctional binding protein. Nature 329:301-307

52. Rees-Jones RW, Taylor SI (1985) An endogenous substrate for the insulin receptor-associated tyrosine kinase. J Biol Chem 260 : 4461-4467

53. Sadoul JL, Peyron JF, Ballotti R, Debant A, Fehlman M, van Obberghen E (1985) Identification of a cellular 110,000-Da protein substrate for the insulin receptor kinase. Biochem J 227: $887-892$

54. Häring HU, White MF, Machicao F, Ermel B, Schleicher E, Obermaier B (1987) Insulin rapidly stimulates phosphorylation of a $46 \mathrm{kDa}$ membrane protein on tyrosine residues as well as phosphorylation of several soluble proteins in intact fat cells. Proc Natl Acad Sci USA 84: 113-117

55. Bernier M, Laird DM, Lane MD (1987) Insulin-activated tyrosine phosphorylation of a 15-kilodalton protein in intact 3T3-L1 adipocytes. Proc Natl Acad Sci USA 84: 1844-1848

56. Denton RM, Brownsey RW, Belsham GJ (1981) A partial view of the mechanism of insulin action. Diabetologia 21: 347-362

57. Avruch J, Alexander MC, Palmer JL, Pierce MW, Nemenoff RA, Blackshear PJ, Tipper JP, Witters LA (1982) Role of insulinstimulated protein phosphorylation in insulin action. Fed Proc 41: 2629-2633

58. Brownsey RW, Denton RM (1982) Evidence that insulin activates fat-cell acetyl-CoA carboxylase by increased phosphorylation at a specific site. Biochem J 202: 77-86

59. Yu KT, Khalaf N, Czech MP (1987) Insulin stimulates a membrane-bound serine kinase that may be phosphorylated on tyrosine. Proc Natl Acad Sci USA 84: 3972-3976

60. Ray LB, Sturgill TW (1988) Insulin-stimulated microtubule-associated protein kinase is phosphorylated on tyrosine and threonine in vivo. Proc Natl Acad Sci USA 85: 3753-3757

61. Stralfors P, Belfrage P (1983) Phosphorylation of hormone-sensitive lipase by cyclic AMP-dependent protein kinase. J Biol Chem 258: $15146-15152$

62. Parker PJ, Candwell FB, Cohen P (1983) Glycogen synthase from rabbit skeletal muscle. Effect of insulin on the state of phosphorylation of the seven phosphoserine residues in vivo. Eur $\mathbf{J}$ Biochem 130: 227-234

63. Gibbs EM, Allard WJ, Lienhard GE (1986) The glucose transporter in 3T3-L1 adipocytes is phosphorylated in response to phorbol ester but not in response to insulin. J Biol Chem 261: 16659-16603

64. Joost HG, Weber TM, Cushman SW, Simpson IA (1987) Activity and phosphorylation state of glucose transporters in plasma membranes from insulin-, isoproterenol-, and phorbol estertreated rat adipose cells. J Biol Chem 262: 11261-11267

65. Delvecchio R, Pilch PF (1989) Insulin-induced phosphorylation of the insulin-sensitive glucose transporter. Diabetes 38 [Suppl.2]: 85A (Abstract)

66. Lawrence J, Hiken JF, James DE (1989) Phosphorylation of the insulin-regulatable glucose transporter (IRGT). Diabetes 38 [Suppl.2]: 85A (Abstract) 
67. O'Brien RM, Houslay MD, Milligan G, Siddle K (1987) The insulin receptor tyrosyl kinase phosphorylates holomeric forms of the guanine nucleotide regulatory proteins $G_{i}$ and $G_{0}$. FEBS Lett 212: 281-288

68. Krupinsky J, Rajaram R, Lakonishok M, Benovic JL, Cerione RA (1988) Insulin-dependent phosphorylation of GTP-binding proteins in phospholipid vesicles. J Biol Chem 263: 12333-12341

69. Zick Y, Sagi-Eisenberg R, Pines M, Gierschik P, Spiegel AM (1986) Multisite phosphorylation of the alpha subunit of transducin by the insulin receptor kinase and protein kinase C. Proc Natl Acad Sci USA 83: 9294-9297

70. Joost HG (1989) Phosphorylation of G-proteins in intact adipose cells as studied by immunoprecipitation with antiserum against a common peptide sequence of G-protein alpha-subunits. Naunyn-Schmiedeberg's Arch Pharmacol 339 [Suppl.]: R34 (Abstract)

71. Joost HG, Schmitz-Salue C, Hinsch KD, Schultz G, Rosenthal W (1989) Phosphorylation of G-protein alpha-subunits in intact adipose cells: evidence against a mediating role in insulin-dependent metabolic effects. Eur J Pharmacol (Molec Pharmacol Section) (in press)

72. Green A (1983) Catecholamines inhibit insulin-stimulated glucose transport in adipocytes, in the presence of adenosine deaminase. FEBS Lett 152: 261-264

73. Smith U, Kuroda M, Simpson IA (1984) Counter-regulation of insulin-stimulated glucose transport by catecholamines in the isolated rat adipose cell. J Biol Chem 259: 8758-8763

74. Joost HG, Göke R (1984) Effects of islet-activating protein on insulin- and isoprenaline-stimulated glucose transport in isolated rat adipocytes. FEBS Lett $167: 5-9$

75. Joost HG, Göke R, Steinfelder HJ (1985) Dual effect of isoprenaline on glucose transport and response to insulin in isolated adipocytes. Biochem Pharmacol 34: 649-653

76. Joost HG, Steinfelder HJ (1982) Modulation of insulin sensitivity by adenosine. Effects on glucose transport, lipid synthesis, and insulin receptors of the adipocyte. Mol Pharmacol 22: 614-618

77. Kuroda M, Honnor RC, Cushman SW, Londos C, Simpson IA (1987) Regulation of insulin-stimulated glucose transport in the isolated rat adipocyte. cAMP-independent effects of lipolytic and antilipolytic agents. J Biol Chem 262: 245-253

78. Shanahan MF, Edwards BM, Ruoho AE (1986) Interactions of insulin, catecholamines and adenosine in the regulation of glucose transport in the isolated rat cardiac myocytes. Biochim Biophys Acta 887: 121-129

79. Weber TM, Joost HG, Kuroda M, Cushman SW, Simpson IA (1988) Isoproterenol-induced reduction in insulin sensitivity correlates with augmented insulin receptor internalization and dephosphorylation in rat adipose tissue. J Cell Biol 107: 702A (Abstract)

80. Kirsch DM, Baumgarten M, Deufel T, Rinninger F, Kemmler W, Häring HU (1983) Catecholamine-induced insulin resistance of glucose transport in isolated rat adipocytes. Biochem $\mathrm{J} 216$ : 737-745

81. Pessin JE, Gitomer W, Oka Y, Oppenheimer CL, Czech MP (1983) Beta-adrenergic regulation of insulin and epidermal growth factor receptors in rat adipocytes. J Biol Chem 258: 7386-7394

82. Steinfelder HJ, Joost HG (1982) In vitro effects of theophylline on insulin receptors in adipocytes. Correlation with the lipolytic action of the agent. Biochem Biophys Res Comm 104: 45-51

83. Joost HG, Steinfelder HJ (1983) Effects of theophylline on insulin receptors and insulin action in the adipocyte. Mol Cell Biochem 57: 177-183

84. Steinfelder HJ, Joost HG (1983) Reversible reduction of receptor affinity by ATP depletion in rat adipocytes. Biochem $\mathrm{J} 214$ : 203-207

85. Arsenis G, Livingston JN (1986) Isoproterenol reduces insulin stimulation of hexose uptake by rat adipocytes via a post-insulin binding alteration. Endocrinology 119:50-57
86. Häring HU, Kirsch D, Obermeier B, Ermel B, Machicao F (1986) Decreased tyrosine kinase activity of insulin receptor isolated from rat adipocytes rendered insulin resistant by catecholamine treatment in vitro. Biochem $\mathrm{J} 234: 59-66$

87. Joost HG, Weber TM, Cushman SW, Simpson IA (1986) Insulinstimulated glucose transport in rat adipose cells. Modulation of transporter intrinsic activity by isoproterenol and adenosine. J Biol Chem 261: 10033-10036

88. Kirsch D, Obermaier B, Häring HU (1985) Phorbolesters enhance basal D-glucose transport but inhibit insulin stimulation of D-glucose transport and insulin binding in isolated rat adipocytes. Biochem Biophys Res Commun 128: 824-832

89. Farese RV, Standaert ML, Barnes DE, Davis JS, Pollet RJ (1985) Phorbol ester provokes insulin-like effects on glucose transport, amino acid uptake, and pyruvate dehydrogenase activity in cultured $\mathrm{BC} 3 \mathrm{H}-1$ cultured myocytes. Endocrinology 116: $2650-2655$

90. Saltis J, Simpson IA, Cushman SW (1988) C-Kinase mediates glucose transporter translocation without stimulation of transport activity in rat adipocytes. Diabetes 37 [Suppl.1]: 41A (Abstract)

91. Mühlbacher C, Karnieli E, Schaff P, Obermaier B, Mushack J, Rattenhuber E, Häring HU (1988) Phorbol esters initiate in rat fat-cells the full effect of insulin on glucose-carrier translocation, but not on 3-0-methylglucose-transport activity. Biochem J 249: 865-870

92. Daly JW (1984) Forskolin, adenylate cyclase, and cell physiology: an overview. Adv Cyclic Nucleotide Protein Phosphorylation Res 17: 81-89

93. Seamon KB, Daly JW (1983) Forskolin, cyclic AMP and cellular physiology. Trends Pharmacol Sci 4: 120-123

94. Joost HG, Steinfelder HJ (1987) Forskolin inhibits insulin-stimulated glucose transport in rat adipose cells by a direct interaction with the glucose transporter. Mol Pharmacol 31:279-283

95. Kim HD, Sergeant S, Shukla DS (1986) Glucose transport in human platelets and its inhibition by forskolin. J Pharmacol Exp Ther 236: 585-589

96. Sergeant S, Kim HD (1985) Inhibition of 3-0-methylglucose transport in human erythrocytes by forskolin. J Biol Chem 662 : 245-253

97. Joost HG, Habberfield AD, Simpson IA, Laurenza A, Seamon KB (1988) Activation of adenylate cyclase and inhibition of glucose transport in rat adipocytes by forskolin analogues: structural determinants for distinct sites of action. Mol Pharmacol 33: 449-453

98. Wadzinsky BE, Shanahan MF, Ruoho AE (1987) Derivatization of the human erythrocyte glucose transporter using a novel forskolin photoaffinity label. J Biol Chem 262: 17683-17689

99. Wadzinsky BE, Shanahan MF, Simpson IA, Joost HG (1988) Photoaffinity labeling of the adipocyte glucose transporter with $\left[{ }^{125} \mathrm{I}\right]$-IAPS-forskolin. FASEB-Journal 2: A584 (Abstract)

100. Joost HG, Schürmann A, Habberfield AD, Simpson IA, Wadzinsky BE, Ruoho AE (1988) Specific labeling of the presumed glucose transporter in adipocyte plasma membranes with a photoreactive forskolin derivative. Naunyn-Schmiedeberg's Arch Pharmacol 338 [Suppl.2]: R28 (Abstract)

101. Steinfelder HJ, Schramm S, Joost HG (1987) Prostaglandin E (2) differentiates between two forms of glucose transport inhibition by lipolytic agents. Naunyn-Schmiedeberg's Arch Pharmacol 336: $105-110$

102. Steinfelder HJ, Joost HG (1988) Inhibition of glucose transport in rat adipocytes by nucleoside transport inhibitors. FEBS Lett 227: $215-219$

Dr. H.G. Joost

Institute of Pharmacology and Toxicology

Robert-Koch-Straße 40

D-3400 Göttingen

FRG 